\title{
Contingency Approaches to Structuring Entrepreneurial New Ventures in Turbulent Environments
}

\author{
Ayishat Omar \\ Rowan University \\ Robert P. Singh \\ Morgan State University
}

New ventures are considered to be vulnerable especially during their infancy with many failing to develop into thriving, prosperous businesses. A major factor that determines survival and success is the environment in which they operate. Static/placid environments exist at one end of a continuum where there is no change and turbulent environments exist at the other end where all factors are continually changing. Given the recorded failure rate of start-ups, this paper proposes a contingency model for how new ventures can be structured in turbulent environments. Ultimately, we suggest that these firms will perform better if they have organic structures.

Keywords: Entrepreneurial New Ventures, Survival, Growth, Turbulence, Environmental Factors

\section{INTRODUCTION}

Entrepreneurship and new venture creation are responsible for much of the growth (Cornwall, 2008; Reynolds, Carter, Gartner, \& Greene, 2004), job creation (Scarborough, Wilson, \& Zimmerer, 2009; Van Stel, \& Storey, 2004), and wealth creation in the U.S. (Ireland, Hitt, Camp, \& Sexton, 2001). New ventures depend on the environment for their resources and information, and face many potential hazards including the lack of resources and inadequate knowledge of environments (Song, Podoynitsyna, Bij, \& Halman, 2008; Stinchcombe, 1965).

It is widely known that new ventures fail at a high rate. According to U. S. Census Bureau and the U.S. Bureau of Labor Statistics data on the survival rates of firms, only 50, 49, and 47 percent of new ventures started in 1995, 2000, and 2005 respectively were still in existence five years after they were started (Shane, 2012). Similarly, the U.S. Small Business Administration's Office of Advocacy (2014) report that about 50 percent of new ventures fail within five years of formation. Research has been consistent in showing that this firm failure rate has remained fairly constant over the last several decades (Audretsch \& Mahmood, 1995; Cader \& Leatherman, 2011; Dunne, Robertson, \& Samuelson, 1988; Singh, 2008; van Praag, 2003). New ventures are vulnerable especially in their infancy period with many failing to develop into thriving, prosperous businesses (Chaganti \& Chaganti, 2012; Geroski, Mata, \& Portugal, 2010). 
It should be recognized that firms operate in different environments (Emery \& Trist, 1965). Static/placid environments exist at one end of a continuum where there is no change and turbulent environments exist at the other end where all factors are continually changing (Smart \& Vertinsky, 1984). A turbulent environment is the most complex of all environment types and presents challenges that require flexibility (Emery \& Trist, 1965). Turbulence, also known as rapid unforeseen changes in the environment, presents organizations with constantly changing problems and higher uncertainty relative to the placid/stable environment; such an environment requires organizations to be flexible to survive and perform well (Drucker, 2011). Instability arises when change is occurring quickly from different sources in the environment, such as from competitors or technology (Barrows \& Neely, 2011). This can create opportunities and challenges for new ventures.

Firm performance is contingent upon fit between organizational context and the environment (Van de Ven \& Drazin, 1984), and survival and success requires internal processes of firms to match external environmental requirements (Sirmon, Hitt, \& Ireland, 2007). Research suggests that organization structured to operate in placid/stable environment may not cope well in a complex, rapidly changing environment (Gordon \& Narayanan, 1984). Relative to a stable environment, a turbulent environment is more complex and external factors become less predictable and more uncertain as the environment becomes more turbulent (Kew \& Stredwick, 2005). Thus, it is critical that entrepreneurs consider the effects of environmental factors on their new ventures and align their structures to fit the challenges posed by the external environment to be able to perform well (Covin \& Slevin, 1990; Sine, Mitsuhashi, \& Kirsch, 2006).

Organizational structures provide the foundations within which organizations function (Dalton, Todor, Spendolini, Fielding, \& Porter, 1980; Pugh, Hickson, Hinings, \& Turner, 1968). A firm's structure provides guidance to employees within the organization and tells them how the organization is put together and how it works. Burns and Stalker (1961) argued that organizations are better off adopting organic structures, characterized by decentralization, lack of specialization, and informal roles, in turbulent environments because they allow organizations to be better positioned to react to dynamism and uncertainty in the environment. Research supports the concept that mature organizations and not just new ventures should adopt organic structures in turbulent environments (Sine, et al., 2006) because new ventures do not need such flexibility since at inception they suffer from liability of newness (Stinchcombe, 1965). However, the extant literature argues that higher environmental uncertainty requires organizations to be adaptive, have roles open to continual redefinition and have considerable lateral communication (Burns \& Stalker, 1961; Child, 1972; Lawrence, Lorsch, \& Garrison, 1967; Stinchcombe, 1965). There is mixed evidence as to the most suitable structure that will enable new ventures to perform well in turbulent environments. In this paper, we seek to examine how new ventures can be structured to perform well in turbulent environments.

This paper explores how organizational structure affects performance of new ventures in turbulent environment. We first offer a discussion on the existing literature on structure, environment, and performance. Following this, we build on management literature and offer three propositions. We close with a discussion of the implications of the paper and conclusions.

\section{LITERATURE REVIEW AND PROPOSITIONS}

Prior research recognizes that the environment influences organizations (Child, 1972; Emery \& Trist, 1965; Scott \& Davis, 2007; Sine, et al., 2006). Emery and Trist (1965) noted that the environments within which organizations operate differ and change in their causal texture, with regards to the degree of uncertainty. Such changes affect organizations. They identified four causal textures, ranging from placidrandomized to turbulent-field environment that organizations might confront (Emery \& Trist, 1965).

The first type, the placid-randomized environment, has relatively unchanging resources, low uncertainty, and environmental demands that are randomly distributed. There are no distinctions between tactics and strategy. Due to the nature of this environment, organizations can exist adaptively as single and small units. The second type, the placid-clustered environment, is characterized by unchanging 
resources and clustered threats. Location and distinctive competence is important in this environment because some positions are discernibly more beneficial than others. It is also beneficial for organizations to strategize and have good knowledge of the environment. Under this environment type, organizations tend to grow in size, become hierarchical, and tend to have centralized coordination and control. The third type, the disturbed-reactive environment, is more complex than the first two. There are many similar organizations in this environment, each seeking to hinder the other. Therefore, strategy and flexibility are important in order for organizations to be able to obtain resources, and make and meet competitive challenges. The fourth environment, the turbulent-field, has the highest level of uncertainty and dynamism. The dynamism here arises from interactions amongst organizations, as well as from the field itself (Emery \& Trist, 1965). Relative to the other three fields, the turbulent environment has the highest level of uncertainty which significantly affects organizations' operations and access to resources.

Turbulence refers to difficult-to-predict discontinuities in the environment and can stem from various sources such as increasing global competition, accelerating technological change, government regulations, amongst others (Drucker, 2011). In turbulent environments the ground keeps moving, dynamism is not just from the interaction of the component organizations but also from the environment field itself (Emery \& Trist, 1965). An organization is likely to be easily caught unaware if the nature of its environment changes rapidly and the organization is not well set up to react to such changes.

We believe that because of the rapid advancement of increasingly powerful and ever more affordable information technologies, increased communications around the world, and the speed at which global competition is rising, more and more firms are operating in turbulent environments. As such, we focus our discussion on the fourth type of environment, the turbulent environment. A recent example of an industry operating in a turbulent environment is the cyber security industry (Biener, Eling, \& Wirfs, 2014; Morgan, 2018; Schackelford, 2016; Wymer, 2018).

\section{Cybersecurity Start-ups}

The cybersecurity industry has been an attractive industry for investors (Austin, 2018; Cunningham, 2018; Morgan, 2018). With increases in data breaches and ransomware in the last few years, corporations worldwide are investing record amounts in cybersecurity products (Cunningham, 2018; Yadron, 2015), and there has been a rush of entrepreneurs into this industry (Yadron, 2015). Companies such as Facebook, Target, Home Depot, amongst others, have fallen prey to cyberattacks. Such attacks have increased the instability in the marketplace for companies providing cybersecurity products (Cybersecurity Industry Report, 2014). Therefore cybersecurity providers will be faced with changing demands to be able to create secure solutions for their clients.

The cybersecurity industry is unique as companies start out with solving problems and every piece of new security technology is usually a data breach away from being obsolete (Yadron, 2015). Many of the start-up in this industry have a short life span relative to start-ups in other industries; some end up merging or facing hostile take-over (Baker, 2018). Yet there has been an increase of investment funding into the industry to emerging cybersecurity companies, with a record high of $\$ 1.71$ billion invested in 240 venture capital deals to emerging cybersecurity companies (Cybersecurity Industry Report, 2014). For such new ventures to thrive and survive in the cybersecurity industry, flexible structures that will allow them to meet the changing demands in this industry are required (Cybersecurity Industry Report, 2014).

The new venture creation process itself is fraught with uncertainty and experimentation (Sarasvathy, 2001; Sommer, Loch, \& Dong, 2009), and turbulence affects it (Drucker, 2011; Shane, 2012). As discussed earlier, about 50 percent of new ventures founded in the U. S. fail within five years (Shane, 2012; U.S. Small Business Administration's Office of Advocacy, 2014). Increased instability in the environment leads to a new set of operating conditions for such new ventures. Contingency theorists argue that organizations can adapt to environmental changes in order to survive (Burns \& Stalker, 1961; Lawrence \& Lorsch, 1967). Burns and Stalker (1961) proposed that organizational performance is contingent on structure. The structure best suited for turbulent environments is expected to be different from that in stable environments. The argument is that the nature of the environment determines the form or structure of organizations. Mechanistic forms are more likely to develop in stable environments while 
organic structures are more apt to develop in dynamic environments. Organizations can oscillate between these two forms depending on if the environment oscillates between stability and change (Burns \& Stalker, 1961).

Contingency theory helps us to understand how organizations effectively deal with their environments. It enables us to be able to make a connection between the varying technical and economic conditions outside the organization and the patterns of organization that lead to successful performance (Lawrence \& Lorsch, 1967). Burns and Stalker (1961) argued that firms with organic structures fare better in a dynamic environment. Others argue that mature organizations in turbulent environments perform better if they have organic structures (Aiken, Bacharach, \& French, 1980; Covin \& Slevin, 1989). Furthermore, using a sample of Internet service ventures from 1996-2001, Sine and associates (2006) argue that new ventures with mechanistic structures fare better. One of the limitations they cited is that their results may not be generalizable to sectors with different characteristics than the Internet sector (Sine, et al., 2006). For their setting, capital barriers to the Internet sector were limited and firm's new technology could be adapted to many existing industries and activities. This is not the case with the cybersecurity industry where technology gets obsolete quickly. Thus, it is unclear whether their results apply to the cybersecurity sector, a more dynamic sector.

For the purpose of this paper, structural dimensions refer to policies and activities occurring within organizations that prescribe or restrict behavior of organizational members (Dalton et al., 1980; Pugh et al., 1968). Five dimensions of structure were operationalized as specialization, standardization, formalization, centralization, and configuration (Pugh et al., 1968). This paper will focus on specialization, formalization, and centralization because past research suggests that they are more applicable to new ventures (Baron, Hannan, \& Burton, 1999; Pugh, et al., 1963; Sine, et al., 2006; Stinchcombe, 1965).

\section{Specialization}

The first structural attribute we examine is specialization. Specialization refers to the number of different occupational titles or functional activities pursued within an organization (Dalton, et al., 1980; Pugh, et al., 1968). On one hand, specialization reduces the flexibility of an organization to react to changes in the environment (Burns \& Stalker, 1961) but also enables tasks to be narrowly defined thereby improving information processing within organizations (Sine, et al., 2006). Dynamism requires a high degree of flexibility so that employees within organizations are better able to respond to changing environment factors (Gual \& Ricart, 2001). In a dynamic environment, specialization can become a double-edged sword (Peteraf, 1993). While it can be a source of competitive advantage by fostering mutual dependency, it can also reduce an organization's flexibility to respond to environmental changes (Burns \& Stalker, 1961; Peteraf, 1993). A dynamic environment requires flexible workers and firmspecific skills can quickly become obsolete.

With specialization, employees perform tasks that are relevant to their specialized functions only, which allows for accumulation of task-related knowledge and improves information processing capabilities (Thompson, 1967). This can be an asset in stable environment because this limits the mobility of such asset and the asset cannot be easily bid away from the organization (Peteraf, 1993). But when faced with environmental uncertainty and changes, such asset may become less flexible and responsive to changing demand (Peteraf, 1993). More formally, we propose the following:

Proposition 1: For new ventures operating in turbulent environments, specialization will be negatively related to performance.

\section{Formalization}

Formalization refers to the extent to which appropriate behavior is described in writing (Dalton, et al., 1980; Pugh, et al., 1968). New ventures initially lack formalization which is a liability because it increases role ambiguity (Stinchcombe, 1965) but in dynamic environments, formalization reduces an organization's ability to adapt to changes and also increases the risk of failure (Burns \& Stalker, 1961). 
Research has found that formalization has a negative impact on mature organizations operating in turbulent environment (Glisson \& Martin, 1980; Wally \& Baum, 1994).

Past research suggests that firms set up to deal with stable markets may not be suitable in uncertain environments and having formal rules and policies in such stable environments will not constrain employees (Tran \& Tian, 2013). High formalization involves situations where rules and policies are explicitly laid out and this may likely impede spontaneity and flexibility required for innovation in uncertain and dynamic environments (Chen \& Huang, 2007). Drawing on these arguments, the following is proposed:

Proposition 2: For new ventures operating in turbulent environments, formalization will be negatively related to performance.

\section{Centralization}

Centralization involves the locus of authority to make decisions affecting the organization (Pugh, et al., 1968; Dalton, et al., 1980). The excessive centralization of decision-making power in the form of formal checks, and controls can create constraints to organizations (Caruana, Morris, \& Vella, 1998). Concentrated power arrangements tend to prevent imaginative solutions since centralized decision making often translates into processes that run counter to the requirements of a creative environment (Caruana, et al., 1998). A creative environment is engendered in organic organizations with flat structures and lateral and not vertical form of communication (Burns \& Stalker, 1961). Centralization can result in an environment that reduces communication and commitment amongst employees, especially when communication takes the form of issuance of commands rather than consultations (Chen \& Huang, 2007).

In organizations characterized by high centralization, many important decisions are made by higher level employees, whereas in decentralized organizations, lower level employees also make decisions and solve problems (Schminke, Ambrose, \& Cropanzano, 2000). This may be advantageous because they are usually closer to the problems in question. Many organizations find that centralization of decision making could result in inefficiencies (Miller, Droge, \& Toulouse, 1988). Thus, we propose that:

Proposition 3: For new ventures operating in turbulent environments, centralization will be negatively related to performance.

\section{DISCUSSION}

Given the increased turbulence in today's environment (Drucker, 2011; Hamilton \& Webster, 2015), organizations must learn to cope with it in order to be able to survive. Organizations stand to lose if they are unable to quickly recognize the changing texture of their environment or if they are unable to keep up with such changes (Emery \& Trist, 1965). Contingency theorists argue that organizations can adapt to environmental changes. If rapidly changing environments require certain kinds of organizational structures, then the organization can adapt its structure to fit the environment (Pfeffer \& Salancik, 1978). Further study and empirical testing of the propositions should shed more insight into how structure moderates the relationship between the environment and performance of new ventures - specifically within turbulent environments. A well-designed organizational structure - one that matches the environment - promotes success and businesses require structure to grow and be successful (Teece, 2010).

Burns and Stalker (1961) classified different set of structures as mechanistic or organic. In mechanistic systems, duties and power attached to each role are precisely defined, and interaction with management tends to be vertical (superior to subordinate). All knowledge is available only to the head of the firm and knowledge/information flows up, while decisions and knowledge flow down. Organic systems are adapted to unstable conditions where individuals have to perform tasks in light of their knowledge and the tasks of the firm as a whole. Jobs lose their formal definition and interaction runs 
laterally. Different kinds of organizations are necessary for coping with different strategies and environments (Child, 1972).

New ventures fail at a high rate in the U.S., but there are still some new ventures that survive and also perform well. The firms that do well in turbulent environments must be doing something different from their counterparts who do not. We believe that our propositions lay out key differences, and further, if empirical testing of the propositions provides support, entrepreneurs in the process of new venture creation will have another tool for improving their chances for survival and success. More specifically, they will have further guidance as to how best to structure their firms when operating in turbulent environments. It is imperative to study contingencies since the technological, geographical, and economic conditions facing organizations are changing constantly, more rapidly and drastically.

Additionally, the success of new ventures is important since research has shown that they are major contributors to the U.S. economy (Ireland, et al., 2001; Kirchhoff, 1991) and job creation (Kritikos, 2014). A productive economy can translate into better standard of living for the populace. Therefore more research into how they can best recognize opportunities in the environment and also adapt to challenges will be beneficial to the economy and the populace.

\section{Future Research Directions and Implications for Practice}

An organization's ability to rapidly respond to changes in its environment cannot be over emphasized. Unpredictable changes in the environment can disrupt the operations and performance of an organization and could ultimately lead to the failure of the organization. New ventures therefore have to be structured in such a way that they are not constrained and do not fail when faced with turbulence.

To empirically test the propositions presented in this paper, a longitudinal study for a subset of new ventures is needed (perhaps several hundred firms). The contact information and backgrounds of these firms can be accessed through data aggregation firms such as Dun and Bradstreet. The structures of these firms should be identified at firm founding, or at the very latest soon after founding. The firms should then all be tracked and their performance assessed over their first five years of existence. Such a study would allow the propositions to be tested and reveal whether failed firms or poorer performing firms have different structures from those that succeed. The research design should control for size and industry of the firms, and concurrent studies could be conducted using firms in several industries. We expect that firms with organic structural forms would reveal themselves to be most suited to turbulent environment given the importance of flexibility that such structure affords to new ventures.

Another avenue for future research, and one that might prove easier and quicker to evaluate results, would be to find out the flow of venture capital during turbulent times. Venture capital has been documented to flow to areas with higher risk-reward relationship (Cybersecurity Industry Report, 2014). This would also make clear the opportunities present in the turbulent environment. Information garnered here would be helpful to new ventures, investors, and the populace.

\section{CONCLUSIONS}

This paper focused on studying how the structure adopted by new ventures affect the environmentperformance relationship. Literature has documented that stable environment presents low risk to organizations but turbulent environment has a higher uncertainty and dynamism and therefore results in higher failure rates of start-up firms. Additionally, the basic argument in management literature is that mechanistic organizations are more suitable in stable/placid environments while organic structures are more appropriate in turbulent environment. We believe that further testing is needed to better understand the role that strategic choice of organizational structure can play in determining performance of new ventures, particularly those which operate in increasingly turbulent environments.

We realize that the discussion herein is broad, but as further study is conducted and the propositions are studied and perhaps supported, we believe future studies can become more refined and specific. Much more future research, particularly longitudinal research, is certainly needed to better understand how to improve entrepreneurial success that the realm of possibilities is wide open. We hope this paper helps to 
highlight a potential source of study for researchers to better understand how to help entrepreneurs improve their chances for success.

\section{REFERENCES}

Aiken, M., Bacharach, S. B., \& French, J. L. (1980). Organizational structure, work process, and proposal making in administrative bureaucracies. Academy of Management Journal, 23(4), 631-652.

Audretsch, D., \& Mahmood, T. (1995). New firm survival: New results using a hazard function. The Review of Economics and Statistics, 77(1), 97-103.

Austin, J. (2018). Cyber drivers: Why investment in cybersecurity is taking off. Retrieved from https:/www.cbronline.com/opinion/cybersecurity-market-investment-livingstone

Baker, L. (2018). Under threat: Cyber security startups fall on harder times. Retrieved from https://www.reuters.com/article/us-cybersecurity-startups-analysis/under-threat-cyber-securitystartups-fall-on-harder-times-idUSKBN1F62RW

Baron, J. N., Hannan, M. T., \& Burton, M. D. (1999). Building the iron cage: Determinants of managerial intensity in the early years of organizations. American Sociological Review, 527-547.

Barrows, E., \& Neely, A. (2011). Managing performance in turbulent times: Analytics and insight. John Wiley \& Sons.

Biener, C., Eling, M., \& Wirfs, J. H. (2018). Insurability of cyber risk. Methodology, 9.

Burns, T., \& Stalker, G. M. (1961). The management of innovation. Chicago: Quadrangle Books, Inc.

Cader, H. A., \& Leatherman, J. C. (2011). Small business survival and sample selection bias. Small Business Economics, 37(2), 155-165.

Caruana, A., Morris, M., \& Vella, A. (1998). The effect of centralization and formalization on entrepreneurship in export firms. Journal of Small Business Management, 36(1), 17-29.

Chaganti, R. S., \& Chaganti, R. (2012). Pathways to failure of new ventures: Markers of failed internet ventures. Journal of Management and Public Policy, 4(1), 4.

Chen, C. J., \& Huang, J. W. (2007). How organizational climate and structure affect knowledge management-The social interaction perspective. International Journal of Information Management, 27(2), 104-118.

Child, J. (1972). Organizational structure, environment and performance: The role of strategic choice. Sociology, 6(1), 1-22.

Cornwall, A. (2008). Unpacking participation models, meanings and practices. Community Development Journal, 43(3), 269-283.

Covin, J. G., \& Slevin, D. P. (1989). Strategic management of small firms in hostile and benign environments. Strategic Management Journal, 10(1), 75-87.

Covin, J. G., \& Slevin, D. P. (1990). New venture strategic posture, structure, and performance: An industry life cycle analysis. Journal of Business Venturing, 5(2), 123-135.

Cunningham, S. (2018). Cybersecurity in 2018: broader scope of innovation and bigger venture dollars. Venture Capital Journal, 58(3), 56.

Cybersecurity Industry Report (2014). Retrieved from https://www.cbinsights.com/blog/cybersecurity-industry-report/.

Dalton, D. R., Todor, W. D., Spendolini, M. J., Fielding, G. J., \& Porter, L. W. (1980). Organization structure and performance: A critical review. Academy of Management Review, 5(1), 49-64.

Drucker, P. (2011). Turbulence and performance management today. In Barrows, E. and Neely, Managing performance in turbulent times: Analytics and insight. New York: John Wiley and Sons.

Dunne, T., Roberts, M. J., \& Samuelson, L. (1988). Patterns of firm entry and exit in U.S. manufacturing industries. The Rand Journal of Economics, 19(4), 495-515.

Emery, F. E., \& Trist, E. (1965). The causal texture of organizational environments. Human Relations, $18(1), 12-32$. 
Geroski, P. A., Mata, J., \& Portugal, P. (2010). Founding conditions and the survival of new firms. Strategic Management Journal, 31(5), 510-529.

Glisson, C. A., \& Martin, P. Y. (1980). Productivity and efficiency in human service organizations as related to structure, size, and age. Academy of Management Journal, 23(1), 21-37.

Gordon, L. A., \& Narayanan, V. K. (1984). Management accounting systems perceived environmental uncertainty and organization structure: An empirical investigation. Accounting, Organizations and Society, 9(1), 33-47.

Gual, J., \& Ricart, J. E. (eds.) (2001). Strategy, organization and the changing nature of work. Cheltenham: Edward Elgar.

Hamilton, L., \& Webster, P. (2015). The international business environment. Oxford University Press.

Ireland, R. D., Hitt, M. A., Camp, S. M., \& Sexton, D. L. (2001). Integrating entrepreneurship and strategic management actions to create firm wealth. The Academy of Management Executive, 15(1), 49-63.

Kew, J., \& Stredwick, J. (2005). Business environment: Managing in a strategic context. CIPD Publishing.

Kirchhoff, B. A. (1991). Entrepreneurship's contribution to economics. Entrepreneurship Theory and Practice, 16(2), 93-112.

Kritikos, A. S. (2014). Entrepreneurs and their impact on jobs and economic growth. IZA World of Labor.

Lawrence, P. R., Lorsch, J. W., \& Garrison, J. S. (1967). Organization and environment: Managing differentiation and integration (p. 1976). Boston, MA: Division of Research, Graduate School of Business Administration, Harvard University.

Morgan, S. (2018). 2018 Cybersecurity market report. Retrieved from https://cybersecurityventures.com/cybersecurity-market-report/

Miller, D., Dröge, C., \& Toulouse, J. M. (1988). Strategic process and content as mediators between organizational context and structure. Academy of Management Journal, 31(3), 544-569.

Peteraf, M. A. (1993). The cornerstones of competitive advantage: A resource-based view. Strategic Management Journal, 14(3), 179-191.

Pfeffer, J., \& Salancik, G. R. (1978). The external control of organizations: A resource dependence perspective. New York, NY: Harper \& Row.

Pugh, D. S., Hickson, D. J., Hinings, C. R., \& Turner, C. (1968). Dimensions of organization structure. Administrative Science Quarterly, 65-105.

Reynolds, P. D., Carter, N. M., Gartner, W. B., \& Greene, P. G. (2004). The prevalence of nascent entrepreneurs in the United States: Evidence from the panel study of entrepreneurial dynamics. Small Business Economics, 23(4), 263-284.

Sarasvathy, S. D., Menon, A. R., \& Kuechle, G. (2013). Failing firms and successful entrepreneurs: Serial entrepreneurship as a temporal portfolio. Small Business Economics, 40(2), 417-434.

Scarborough, N. M., Wilson, D. L., \& Zimmerer, T. W. (2009). Effective small business management: An entrepreneurial approach (9th Edition), Upper Saddle River, NJ: Prentice Hall.

Schackelford, S. (2016). Protecting intellectual property and privacy in the digital age: The use of national cybersecurity strategies to mitigate cyber risk. Chapman Law Review, 19(2), 445-481.

Schminke, M., Ambrose, M. L., \& Cropanzano, R. S. (2000). The effect of organizational structure on perceptions of procedural fairness. Journal of Applied Psychology, 85(2), 294.

Scott, W. R., \& Davis, G. F. (2007). Organizations and organizing: Rational, natural, and open system perspectives. Prentice Hall.

Shane, S. (2012). Start-up failure rates: The definitive numbers. Small Business Trends. Retrieved from http://smallbiztrends.com/2012/12/start-up-failure-rates-the-definitive-numbers.html.

Sine, W. D., Mitsuhashi, H., \& Kirsch, D.A. (2006). Revisiting Burns and Stalker: Formal structure and new venture performance in emerging economic sectors. Academy of Management Journal, 49(1), 121-132.

Singh, R. P. (2008). Exploring why so many entrepreneurs fail: Is entrepreneurial overconfidence a mental defect? 2008 Academy of Management Meeting. Anaheim, CA, August. 
Sirmon, D. G., Hitt, M. A., \& Ireland, R. D. (2007). Managing firm resources in dynamic environments to create value: Looking inside the black box. Academy of Management Review, 32(1), 273-292.

Smart, C., \& Vertinsky, I. (1984). Strategy and the environment: A study of corporate responses to crises. Strategic Management Journal, 5(3), 199-213.

Sommer, S. C., Loch, C. H., \& Dong, J. (2009). Managing complexity and unforeseeable uncertainty in startup companies: An empirical study. Organization Science, 20(1), 118-133.

Song, M., Podoynitsyna, K., Van Der Bij, H., \& Halman, J. I. (2008). Success factors in new ventures: A meta-analysis. Journal of Product Innovation Management, 25(1), 7-27.

Stinchcombe, A. L. (1965). Organizations and social structure. In J. G. March (Ed.), Handbook of organizations (pp. 142-193). Chicago, IL: Rand McNally.

Teece, D. J. (2010). Business models, business strategy and innovation. Long Range Planning, 43(2), 172-194.

Thompson, J. D. 1967. Organizations in action. New York: McGraw-Hill.

Tran, Q., \& Tian, Y. (2013). Organizational structure: Influencing factors and impact on a firm. American Journal of Industrial and Business Management, 3.

U.S. Small Business Administration Office of Advocacy. (2014). Frequently asked questions about small business. Retrieved from http://www.sba.gov/sites/default/files/FAQ_March_2014_0.pdf

Van de Ven, A. H., \& Drazin, R. (1984). The concept of fit in contingency theory (No. SMRC-DP-19). Minnesota Univ Minneapolis Strategic Management Research Center.

van Praag, M. (2003). Business survival and success of young small business owners. Small Business Economics, 21(1), 1-17.

Van Stel, A. J., \& Storey, D. J. (2004). The link between firm births and job creation: Is there a upas tree effect? Regional Studies, 38(8), 893-909.

Wally, S., \& Baum, J. R. (1994). Personal and structural determinants of the pace of strategic decision making. Academy of Management Journal, 37(4), 932-956.

Wymer, K. V. (2018). Cybersecurity, shareholders, and the boardroom: An analysis of current and proposed measures for protecting corporate intellectual property. Journal of Intellectual Property Law, 25(2), 228.

Yadron, D. (2015). Data breaches boost funding for cybersecurity startups. Wall Street Journal (Online). 